\title{
PENGEMBANGAN PERANGKAT PEMBELAJARAN IPA UNTUK MENINGKATKAN HASIL BELAJAR SISWA
}

\author{
Satwika Trianti Ngandoh'), Endang Susantini'²), I Gusti Made Sanjaya ${ }^{3)}$ \\ ${ }^{1)}$ Mahasiswa Program Studi Pendidikan Sains, Program Pascasarjana Universitas Negeri Surabaya \\ 2), 3)Dosen Pascasarjana Prodi Pendidikan Sains Universitas Negeri Surabaya \\ E-mail: satwikatrianti_ngandoh@yahoo.co.id
}

\begin{abstract}
Abstrak: Penelitian ini bertujuan untuk menghasilkan perangkat pembelajaran IPA yang layak untuk meningkatkan hasil belajar siswa sekolah menengah pertama. Penelitian ini merupakan penelitian pengembangan dengan desain perangkat pembelajaran menggunakan model Dick and Carey dan diujicobakan di kelas VIII SMP Negeri 2 Dlanggu tahun ajaran 2015/2016. Pembelajaran dilakukan dengan cara menerapkan perangkat pembelajaran IPA berbasis inkuiri terbimbing. Sasaran penelitian adalah perangkat pembelajaran. Pengumpulan data menggunakan metode validasi, observasi, tes dan angket. Hasil analisis data penelitian menunjukkan bahwa: (1) perangkat pembelajaran yang dikembangkan valid; (2) pembelajaran terlaksana dengan kategori sangat baik; (3) hasil belajar siswa mengalami peningkatan dengan skor $\mathrm{N}$-gain berkategori tinggi; (4) Siswa memberikan respon positif terhadap pembelajaran. Berdasarkan hasil penelitian tersebut, dapat disimpulkan bahwa perangkat pembelajaran berbasis inkuiri terbimbing yang telah dikembangkan layak digunakan untuk meningkatkan hasil belajar siswa.
\end{abstract}

Kata kunci: Perangkat Pembelajaran, Model Inkuiri Terbimbing, Hasil Belajar.

\begin{abstract}
This research is the development of the design of the learning materials used a model of Dick and Carey and tested in class VIII SMP Negeri 2 Dlanggu even semester in academic year of 2015/2016. Learning takes place by applying the based of guided inquiry learning materials. The research subjectives are learning materials. The data collections used validation, observation, test, and questionnaires methods. The results showed that: (1) a valid learning materials developed; (2) the learning process took place well; (3) the students were more active in learning; (4) the learning achievement of students has increased by a score of N-gain high category; (5) the students responded positively towards learning. Based on the above results, it can be concluded that the guided inquiry learning based materials that have been developed feasible used to improve student learning achievement.
\end{abstract}

Keywords Learning Materials, Guided Inquiry Learning Model, Learning Achievement

\section{PENDAhuluan}

Kualitas pendidikan di Indonesia masih di bawah rata-rata negara berkembang lainnya. Berdasarkan hasil survey Programme for International Student Assessment (PISA) tahun 2015 menunjukkan bahwa kemampuan Indonesia dalam bidang IPA sangat rendah sekali, yaitu peringkat 69 dari 76 negara. Hasil yang rendah ini kemungkinan disebabkan karena siswa-siswi di Indonesia terbiasa mengerjakan soal yang hanya menekankan pada penguasaan konsep saja, namun jarang menekankan kemampuan siswa mengidentifikasi masalah, menyelesaikan masalah dengan menerapkan pengetahuan yang telah diperolehnya ke dalam situasi yang baru, berpikir, berargumentasi, membuat keputusan tentang suatu perubahan, serta mengkomunikasikannya (Mulyasa, 2013)

Berdasarkan hasil observasi yang dilakukan peneliti pada SMP Negeri 2 Dlanggu tentang aktivitas siswa selama kegiatan pembelajaran IPA, diketahui bahwa pembelajaran masih berpusat pada guru (teacher center) dan konsep-konsep IPA yang diperoleh siswa sebagian besar merupakan konsep yang diberikan oleh guru. Siswa hanya belajar menghapal suatu konsep, bukan memahami konsep sehingga pembelajaran IPA menjadi kurang bermakna. Siswa kurang diajak untuk lebih aktif dalam proses pembelajaran. Permasalahan lain dalam pembelajaran IPA di kelas VIII SMP Negeri 2 Dlanggu adalah rendahnya kemampuan siswa dalam memahami materi pada KD 3.5 yaitu menganalisis sistem pencernaan pada manusia danmemahami gangguan yang berhubungan dengan sistem pencernaan, serta upaya menjaga kesehatan sistem pencernaan sehingga menyebabkan aktivitas belajar rendah yang berdampak pada hasil belajar yang kurang memuaskan. Selain itu, proses pembelajaran masih didominasi oleh penyampaian informasi, bukan ditekankan pada pemrosesan informasi. Kegiatan tersebut masih berpusat pada kegiatan mendengarkan 
dan menghapal, bukan interpretasi dan makna terhadap apa yang dipelajari. Guru masih mendominasi proses ini sehingga kurang memberikan peluang bagi siswa untuk berkreasi, berkembang, dan menunjukkan kemampuan yang beragam, sehingga hasil belajar siswa cenderung rendah. Hal di atas terjadi disebabkan karena perangkat pembelajaran khususnya pada rancangan pembelajaran yang dimiliki oleh guru belum memadai untuk peningkatan hasil belajar siswa.

Seringkali karena keterbatasan waktu, guru tidak membuat perangkat pembelajaran sendiri, melainkan mengambil melalui internet. perangkat pembelajaran yang digunakan itu, kadang kurang cocok dengan kondisi yang ada di sekolah. Sehingga yang terjadi adalah langkah-langkah pembelajaran yang ada tidak sesuai dengan pelaksanaannya di kelas.

Salah satu model pembelajaran yang berpotensi dapat meningkatkan hasil belajar siswa adalah model inkuiri terbimbing. Inkuiri menekankan kepada aktivitas siswa secara maksimal untuk mencari dan menemukan, artinya model inkuiri menempatkan siswa sebagai subjek belajar. Dalam proses pembelajaran, tidak hanya berperan sebagai penerima pelajaran melalui penjelasan guru secara verbal, tetapi mereka berperan untuk menemukan sendiri inti dari materi pelajaran itu sendiri (Sanjaya, 2010).

Melalui model inkuiri siswa dapat menguasai konsep sains dan juga dilatih untuk meneliti suatu permasalahan dengan fakta yang ada, dimana siswa melakukan prosedur-prosedur ilmuwan yang digunakan untuk mengenal masalah, mengajukan pertanyaanpertanyaan, mengadakan prosedur-prosedur penyelidikan untuk memperoleh solusi atau jawaban. Model pembelajaran inkuiri merupakan bagian dari pembelajaran dengan penemuan, dimana siswa didorong terlibat secara aktif untuk belajar dengan konsep-konsep dan prinsip-prinsip.

Dalam pembelajaran IPA dengan model inkuiri

terbimbing, guru membimbing siswa yang belum pernah pengalaman belajar dengan kegiatankegiatan inkuiri. Guru tidak lagi berperan sebagai pemberi informasi dan siswa sebagai penerima informasi, tetapi guru dapat membuat rencana pembelajaran atau langkah-langkah percobaan. Siswa melakukan percobaan atau penyelidikan untuk menemukan konsep-konsep yang telah ditetapkan guru.

Siswa dilibatkan secara aktif dengan mencari sendiri untuk mengatasi permasalahan yang sedang dihadapinya. Pembelajaran model inkuiri terbimbing membuat siswa mendapat pemahaman materi ajar yang lebih baik. Pembelajaran melalui model inkuiri terbimbing akan mengubah cara belajar siswa yang selama ini lebih banyak bersifat menunggu informasi dari guru ke pembelajaran yang lebih bersifat bermakna. Pembelajaran inkuiri terbimbing juga mempunyai tujuan untuk mengembangkan kemampuan intelektual siswa, sehingga dalam pembelajaran siswa tidak hanya dituntut agar menguasai pelajaran akan tetapi dapat menggunakan potensi yang dimilikinya. Pembelajaran model inkuiri terbimbing diharapkan mampu meningkatkan hasil belajar siswa. Berdasarkan penelitian terdahulu oleh Maya (2014), yang menunjukkan bahwa motivasi dan hasil belajar peserta didik mengalami peningkatan setelah peserta didik belajar dengan menggunakan model inkuiri terbimbing. Berdasarkan uraian di atas, maka penulis melakukan penelitian dengan judul "Pengembangan Perangkat Pembelajaran IPA Berbasis Inkuiri Terbimbing Materi Sistem Pencernaan Makanan untuk Meningkatkan Hasil Belajar Siswa".

\section{METODE PENELITIAN}

Penelitian ini merupakan jenis penelitian pengembangan perangkat pembelajaran untuk meningkatkan hasil belajar siswa melalui metode pembelajaran berbasis Inkuiri Terbimbing. Perangkat pembelajaran yang dikembangkan meliputi Silabus, Rencana Pelaksanaan Pembelajaran (RPP), Lembar Kegiatan Siswa (LKS), Bahan Ajar, Tes Kemampuan Berpikir Kreatif dan Tes Hasil Belajar (THB). Selain perangkat pembelajaran yang dikembangkan, dilengkapi pula dengan instrument penelitian berupa Lembar validasi perangkat pembelajaran, Lembar Keterlaksaan RPP, dan Lembar Respon siswa terhadap pembelajaran berbasis Inkuiri Terbimbing.

Uji coba dilaksanakan pada semester ganjil di SMP Negeri 2 Dlanggu, Kota Mojokerto. Subyek penelitian ini adalah perangkat pembelajaran IPA berbasis Inkuiri Terbimbing yang dikembangkan dan diujicobakan pada 30 siswa kelas VIII.

Pengembangan perangkat pembelajaran pada penelitian ini mengadaptasi model Dick \& Carey. Proses pengembangan tersebut terdiri atas tahapan sebagai berikut, yaitu: menganalisis KI dan KD, analisis siswa, analisis pembelajaran, merumuskan indikator, menyusun tes acuan patokan, memilih strategi pembelajaran, pengembangan perangkat pembelajaran, validasi perangkat dan revisi, uji coba. Ujicoba perangkat dilakukan dengan menggunakan rancangan ujicoba one group pretest-posttest design karena menggunakan satu kelompok tanpa ada kelompok pembanding.

\section{A. Variabel Penelitian dan Teknik Pengumpulan Data}

1. Variabel Validitas Perangkat Pembelajaran

Deskripsi validitas perangkat ditinjau dari hasil validasi dua pakar pembelajaran. Tujuan validasi perangkat pembelajaran adalah untuk mendapatkan masukan, perbaikan perangkat dan menghasilkan perangkat pembelajaraan yang layak diujicobakan. 


\section{Variabel Kepraktisan Perangkat Pembelajaran}

Kepraktisan perangkat didasarkan pada hasil pengamatan dua pengamat terhadap keterlaksanaan RPP dan sintaks inkuiri terbimbing selama proses pembelajaran. Observasi atau pengamatan dilakukan untuk mengumpulkan data penelitian yang berkenaan dengan sikap dan perilaku/kinerja. Keterlaksanaan RPP diukur melalui pengamatan yang dilakukan oleh dua orang guru bidang studi IPA di SMPN 2 Dlanggu Mojokerto yang bertindak sebagai pengamat (observer) selama proses pembelajaran.

\section{Variabel Keefektifan Perangkat Pembelajaran}

Keefektifan perangkat ditinjau dari dua variabel yaitu minat belajar dan hasil belajar siswa dan respon siswa. Hasil belajar siswa diukur melalui tes hasil belajar yang dilaksanakan sebelum dan setelah proses pembelajaran (sebagai pretest dan posttest). Respon siswa diukur dengan angket respon siswa yang diberikan setelah rangkaian proses pembelajaran selesai.

\section{B. Instrumen Penelitian}

1. Lembar Validasi Perangkat Pembelajaran

Lembar validasi perangkat pembelajaran digunakan sebagai acuan penentuan predikat/kategori perangkat pembelajaran oleh validator. Lembar validasi disertai skor penilaian dan saran terhadap perangkat pembelajaran yang dikembangkan.

2. Lembar Pengamatan Kepraktisan Perangkat

Pembelajaran

Lembar pengamatan kepraktisan perangkat pembelajaran dalam hal ini berupa lembar keterlaksanaan RPP dalam proses pembelajaran. Pengisian lembar pengamatan dilakukan dengan memberi tanda cek (v) pada kolom yang sesuai dengan tahapan pembelajaran, serta memberi skor dari rentang 1-4 yang sesuai. Skala yang digunakan diadaptasi dari Borich (1994). Penilaian kualitas keterlaksanaan RPP ditentukan dengan menghitung rata-rata skor penilaian yang diberikan dua orang pengamat. Selain itu dilakukan perhitungan reliabilitas instrumen untuk menentukan baik tidaknya instrumen yang dikembangkan dengan rumus sebagai berikut:

$$
\mathrm{R}\left[\frac{\mathrm{A}}{\mathrm{D}+\mathrm{A}}\right] \times 100 \%
$$

Keterangan:

$\mathrm{R}=$ Reliabilitas instrumen (percentage agreement)

Frekuensi kecocokan antar kedua penilai

Frekuensi ketidakcocokan antar kedua penilai

Instrumen penilaian perangkat dikatakan reliabel jika nilainya $=75 \%$ (Borich dalam Ibrahim 2005).
3. Lembar Keefektifan Penerapan Pembelajaran

Instrumen kefektifan penerapan pembelajaran berupa lembar soal Tes Hasil Belajar (THB). Soal THB terdiri dari 19 soal pilihan ganda dan 3 soal isian dengan sebaran tingkat kognitif $\mathrm{C} 1-\mathrm{C} 4$. Soal THB digunakan sebagai soal pretest dan posttest. Teknik analisis data dalam penelitian ini menggunakan deskriptif kuantitatif dan kualitatif. Validitas perangkat pembelajaran dikatakan valid jika percentage of agreement $=75 \%$. Selisih antara nilai pretest dan posttest nilai tes pemahaman konsep dilakukan analisis statistik inferensial melalui analisis Ngain. Untuk membandingkan rata-rata dari dua variabel (pretest dan posttest) dalam satu grup data menggunakan uji $t$ sampel berpasangan. Variabel pretest dan posttest untuk mengetahui korelasi sebelum dan sesudah pembelajaran.

\section{HASIL PENELITIAN DAN DISKUSI}

A. Validitas Perangkat Pembelajaran

Hasil validasi perangkat pembelajaran oleh dua orang pakar, yaitu Dosen Universitas Negeri Surabaya tertera pada Tabel 1 berikut:

Tabel 1. Hasil Validasi Perangkat Pembelajaran

\begin{tabular}{|l|l|l|l|l|}
\hline No. & Jenis perangkat & Skor & $\mathrm{R}(\%)$ & Predikat \\
\hline 1 & $\begin{array}{l}\text { Rancangan } \\
\text { pelaksanaan } \\
\text { pembelajaran }\end{array}$ & 3,50 & 89,21 & Baik \\
\hline 2 & $\begin{array}{l}\text { Lembar } \\
\text { kegatan siswa }\end{array}$ & 3,69 & 96,26 & Sangat Baik \\
\hline 3 & $\begin{array}{l}\text { Buku ajar } \\
\text { siswa }\end{array}$ & 3,72 & 97,79 & Sangat Baik \\
\hline 4 & $\begin{array}{l}\text { Lembar } \\
\text { pengamatan } \\
\text { sikap }\end{array}$ & 3,50 & 95,24 & Sangat Baik \\
\hline 5 & $\begin{array}{l}\text { Instrumen tes } \\
\text { hasil belajar }\end{array}$ & 3,88 & 96,75 & Sangat Baik \\
\hline 6 & $\begin{array}{l}\text { Instrumen tes } \\
\text { keterampilan }\end{array}$ & 3,83 & 95,24 & Sangat Baik \\
\hline
\end{tabular}

Keterangan: R : Reliabilitas

Berdasarkan Tabel 1 di atas dapat dimaknai bahwa perangkat pembelajaran yang terdiri dari RPP, LKS, BAS, lembar pengamatan karakter peduli lingkungan dan ngket minat belajar dianggap baik dan layak untuk digunakan (Ratumanan \& Laurens, 2011).

\section{B. Kepraktisan Perangkat Pembelajaran}

Kepraktisan perangkat pembelajaran ditinjau dari keterlaksanaan langkah-langkah pembelajaran berbasis inkuiri terbimbing yang diskenariokan dalam RPP seperti tertera pada Tabel 2 berikut: 
Tabel 2. Hasil Pengamatan Keterlaksanaan RPP

\begin{tabular}{|l|l|l|l|l|l|l|l|l|l|}
\hline \multirow{2}{*}{$\begin{array}{l}\text { Aspek yang } \\
\text { diamati }\end{array}$} & \multicolumn{2}{|l|}{ Part. 1 } & \multicolumn{2}{|l|}{ Part. 2 } & \multicolumn{2}{l|}{ Part. 3 } & \multicolumn{2}{l|}{$\begin{array}{l}\text { Rata- } \\
\text { rata }\end{array}$} \\
\cline { 2 - 10 } & S & P & S & P & S & P & S & p \\
\hline Pendahuluan & 3,8 & B & 4 & SB & 4 & SB & 3,96 & B \\
\hline $\begin{array}{l}\text { Kegiatan } \\
\text { Inti }\end{array}$ & 3,8 & B & 3,9 & B & 3,9 & B & 3,9 & B \\
\hline Penutup & 3,8 & B & 3,8 & B & 4 & SB & 3,9 & B \\
\hline $\begin{array}{l}\text { Pengelolaan } \\
\text { Waktu }\end{array}$ & 4 & SB & 3 & B & 3,5 & B & 3,2 & C \\
\hline $\begin{array}{l}\text { Suasana } \\
\text { Kelas }\end{array}$ & 4 & SB & 4 & SB & 3,8 & B & 3,9 & B \\
\hline
\end{tabular}

Keterangan:

TM : Tatap Muka ke-

S : Skor B : Baik

P : Predikat SB : Sangat Bai

Berdasarkan Tabel 2 di atas dapat dimaknai bahwa fase-fase pembelajaran berbasis inkuiri terbimbing dapat terlaksana dengan baik. Pengamatan keterlaksanaan penggunaan perangkat pembelajaran dilakukan oleh dua orang pengamat yang mencakup 5 tahapan, yaitu kegiatan pendahuluan, kegiatan inti, kegiatan penutup, pengelolaan waktu, dan pengamatan suasana kelas pada saat pembelajaran berlangsung. Pengamatan keterlaksanaan RPP model inkuiri terbimbing pada uji coba II dilakukan selama 3 kali pertemuan yang merupakan implementasi dari RPP pertemuan ke-1, RPP pertemuan ke-2, dan RPP pertemuan ke-3. Berdasarkan analisis data hasil pengamatan keterlaksanaan RPP dapat diketahui bahwa seluruh tahapan berkategori baik, kecuali pada tahapan pengelolaan waktu berkategori cukup. Ratarata persentase dari keterlaksanaan RPP sebesar 97,78\% sehingga dapat dikatakan bahwa pembelajaran terlaksana dengan baik. Pada kegiatan pembelajaran, siswa diorganisasikan dalam kelompoknya untuk merencanakan penyelidikan mengenai organ-organ pencernaan, kerja sistem pencernaan dan gangguan pada sistem pencernaan.

Kemudian siswa mengumpulkan data, dan analisis data guna mengumpulkan sejumlah informasi dengan menggunakan LKS sebagai panduan penyelidikan dimulai dengan apa yang siswa ketahui dan secara aktif melibatkannya dalam mencari jawaban dan penjelasan. Siswa dengan bekerja sama membahas bukti, menganalisis data, membandingkan hasil, dan dengan bimbingan guru menghubungkan hasil mereka dengan pengetahuan ilmiah dan menyimpulkan hasil penyelidikan mereka. Setelah itu, siswa membuat laporan hasil penyelidikan dan mengomunikasikannya. Sebagaimana rumusan yang dikemukakan oleh National Science Education Standard (NRC, 2000) bahwa inkuiri sebagai berbagai bentuk aktivitas yang melibatkan kegiatan pengamatan, mengajukan pertanyaan, mencari rujukan atas data yang diperoleh melalui buku-buku dan sumber informasi lainnya, merencanakan penyelidikan, meninjau ulang apa yang diketahui dari bukti-bukti hasil percobaan sederhana, menggunakan perangkat-perangkat untuk mengumpulkan, menganalisis dan menginterpretasi data, pengajuan jawaban, penjelasan dan perkiraan, serta mengomunikasikan hasil.

\section{Keefektifan Perangkat Pembelajaran}

Keefektifan perangkat pembelajaran dapat ditinjau dari hasil belajar siswa. Hasil belajar yang telah diujicobakan meliputi, aspek sikap, aspek pengetahuan, dan aspek keterampilan.

\section{Aspek Sikap}

Hasil belajar aspek sikap siswa diperoleh melalui data hasil pengamatan terhadap sikap yang muncul pada siswa selama kegiatan pembelajaran berlangsung. Sikap yang diamati meliputi sikap spiritual, sikap disiplin, dan sikap bertanggung jawab. Adapun indikator dari sikap spiritual, yaitu: (a) Berdoa sebelum dan setelah pembelajaran; (b) Mengucapkan syukur ketika berhasil mengerjakan tugas; (c) Memberi salam sebelum dan setelah mempresentaikan hasil pengamatan/percobaan. Indikator sikap disiplin, yaitu: (a) Masuk kelas/laboratorium tepat waktu, (b) Mengerjakan dan mengumpulkan tugas tepat waktu, dan (c) Membawa alat dan bahan percobaan sesuai dengan petunjuk. Indikator sikap bertanggung jawab, yaitu: (a) Mengembalikan alat dan bahan percobaan setelah selesai melakukan kegiatan percobaan; (b) Melakukan percobaan dan mengerjakan tugas yang diberikan dengan bersungguh-sungguh; Membersihkan kelas/laboratorium setelah pembelajaran selesai.

Hasil belajar sikap siswa tidak menggunakan penskoran dan pemberian predikat karena dengan tiga kali pertemuan sebenarnya data belum cukup untuk menentukan keajegan indikator suatu sikap. Sikap adalah suatu nilai yang dianut oleh siswa dan dilaksanakan secara konsisten dan berkelanjutan, maka dari itu pengamatan sikap memerlukan waktu yang lama dan hanya dapat disimpulkan sementara untuk tiga kali pertemuan dengan menggunakan persentase dari sikap yang teramati.

Hasil pengamatan keterlaksanaan indikator sikap spiritual menunjukkan bahwa sebanyak 18 siswa memperoleh predikat sangat baik (SB) dan 12 lainnya memperoleh predikat baik (B). Hal ini menunjukkan bahwa proses pembelajaran yang telah dilaksanakan dapat memperkuat rasa syukur siswa. Hasil pengamatan keterlaksanaan indikator sikap disiplin menunjukkan bahwa 18 siswa yang memperoleh predikat sangat baik dan sisanya 12 siswa memperoleh predikat baik. Hal ini menunjukkan bahwa internalisasi pendidikan sikap 
disiplin dalam pembelajaran IPA berbasis inkuiri terbimbing efektif melatihkan sikap disiplin siswa. Hasil keterlaksanaan indikator sikap bertanggung jawab menunjukkan bahwa sebanyak 20 siswa memperoleh predikat sangat baik dan sisanya sebanyak 10 siswa memperoleh predikat baik. Hal ini menunjukkan bahwa internalisasi pendidikan sikap bertanggung jawab dalam pembelajaran IPA berbasis inkuiri terbimbing efektif melatihkan sikap bertanggung jawab pada siswa.

\section{Aspek Pengetahuan}

Data ketuntasan pretest dan posttest yang telah dipaparkan di atas menunjukkan adanya peningkatan pemahaman dan pengetahuan siswa tentang materi sistem pencernaan makanan. Peningkatan tersebut dapat juga diketahui melalui hasil perolehan skor $\mathrm{N}$-gain yaitu berkisar antara 0,65 sampai 0,88 dimana kategori $\mathrm{N}$-gain tinggi lebih mendominasi. Tes hasil belajar aspek pengetahuan dikatakan baik atau tidak, maka digunakan analisis sensitivitas butir soal. Sensitivitas butir soal yang telah dianalisis menunjukkan perolehan skor dengan rentang 0,4 - 0,8 dengan kategori sensitif (Gronlund, 1977). Hasil yang diperoleh tersebut menunjukkan bahwa tiap butir soal yang telah dikembangkan memiliki kepekaan yang cukup terhadap efek pembelajaran yang diberikan.

Hal ini menunjukkan bahwa peningkatan hasil belajar siswa merupakan efek dari pelaksanaan pembelajaran dengan menggunakan perangkat pembelajaran model inkuiri terbimbing yang telah dikembangkan. Temuan ini sesuai dengan penelitian Nwagbo (1997) (dalam Matthew \& Kenneth, 2013), Timoty dan Awodi (1997), dan Kurumeh (1999) (dalam Matthew \& Kenneth, 2013). Para peneliti ini menyimpulkan bahwa siswa yang diajar menggunakan pembelajaran inkuiri terbimbing mempunyai skor yang lebih baik dibandingkan siswa yang diajarkan dengan pembelajaran konvensional.

\section{Aspek Keterampilan}

Hasil analisis menunjukkan bahwa seluruh siswa dinyatakan tuntas dengan data ketuntasan pretest dan posttest yang telah dipaparkan sebelumnya menunjukkan adanya peningkatan pemahaman akan aspek keterampilan selama proses pembelajaran pada materi sistem pencernaan makanan. Peningkatan tersebut dapat diketahui juga melalui hasil perolehan skor $N$-gain yaitu berkisar antara 0,70 sampai 0,83 dengan kategori tinggi (Hake, 1999).

Ketuntasan belajar siswa aspek keterampilan mencapai $100 \%$. Hal ini menunjukkan bahwa penerapan perangkat pembelajaran inkuiri terbimbing ditinjau dari hasil belajar keterampilan terbukti efektif. Pada pretest, nilai rata-rata siswa masih di bawah nilai ketuntasan minimum disebabkan karena siswa belum terbiasa dengan pembelajaran berbasis inkuiri. Hal ini juga yang menyebabkan pada pertemuan pertama pembelajaran memerlukan waktu yang lebih lama. Guru lebih banyak menjelaskan dan memberikan bimbingan kepada siswa tentang cara-cara membuat rumusan masalah, hipotesis, merancang prosedur kerja, menganalisis data dan membuat kesimpulan. Misalnya pada penyelidikan pencernaan mekanik dan kimiawi, siswa masih sulit untuk membuat hipotesis yaitu dengan menghubungkan antara dua variabel.

Sehingga masih membutuhkan bimbingan guru yang kemudian menghasilkan hipotesis "Air liur menyebabkan zat karbohidrat dalam nasi berubah menjadi gula sederhana". Tetapi secara keseluruhan, berdasarkan hasil ketuntasan tes kinerja untuk keterampilan proses sains sudah mampu menggunakan keterampilan proses sains melalui tes kinerja. Siswa masih memerlukan latihan secara berkelanjutan agar mereka terbiasa untuk menggunakan keterampilan proses sains dalam memecahkan masalahmasalah dalam pelajaran sains dan hasil belajar yang diharapkan dicapai lebih optimal. Sejalan dengan hasil penelitian Praptiwi, Sarwi, Handayani (2012) yang menyimpulkan bahwa pembelajaran IPA dengan menggunakan model inkuiri terbimbing dapat meningkatkan keterampilan proses sains.

\section{Temuan Penelitian}

Berdasarkan hasil analisis dan pembahasan hasil penelitian pengembangan perangkat dan penerapan pembelajaran model inkuiri terbimbing untuk meningkatkan hasil belajar siswa sekolah menengah pertama, diperoleh temuan sebagai berikut:

1. Perangkat pembelajaran dengan model inkuiri terbimbing untuk meningkatkan hasil belajar siswa yang telah dikembangkan dinyatakan valid dan dapat digunakan dalam kegiatan pembelajaran. Pendidikan Sains Pascasarjana Universitas Negeri Surabaya.

2. Keterlaksanaan RPP selama proses pembelajaran dengan rata-rata keseluruhan skor keterlaksanaannya dikategorikan sangat baik.

3. Penerapkan perangkat pembelajaran model inkuiri terbimbing dapat mengembangkan aspek sikap siswa. Hasil belajar aspek sikap spiritual dan sikap sosial dilakukan siswa dengan baik.

4. Penerapan perangkat pembelajaran model inkuiri terbimbing dapat meningkatkan hasil belajar siswa aspek pengetahuan. Peningkatan hasil belajar aspek pengetahuan dapat dilihat dari nilai $N$-gain, yang berkisar antara $0,65-0,88$ dengan kategori tinggi yang lebih mendominasi.

5. Penerapan perangkat pembelajaran model inkuiri terbimbing dapat mengembangkan aspek keterampilan siswa. 

6. Pembelajaran model inkuiri terbimbing mendapatkan respon positif dari siswa.

\section{KESIMPULAN}

\section{A. Simpulan}

Berdasarkan temuan hasil penelitian dapat disimpulkan bahwa perangkat pembelajaran model inkuiri terbimbing yang dikembangkan layak digunakan untuk meningkatkan hasil belajar siswa sekolah menengah pertama pada materi sistem pencernaan makanan.

\section{B. Saran}

1. Persiapan dan pengelolaan waktu perlu diperhatikan, karena pembelajaran berbasis inkuiri terbimbing relatif menghabiskan waktu yang cukup lama.

2. Materi langkah-langkah "Metode Ilmiah" yang telah diajarkan pada semester sebelumnya, perlu diskenariokan dalam pengembangan perangkat pembelajaran berbasis inkuiri terbimbing.

\section{REFERENSI}

Borich, G., D. (2015). Observation Skills for Effective Teaching. New York: McMilan Publishing Company.

Dick, Walter; Carey, Lou \& Carey, James.O. (2009). The Systematic Design of Instruction. New Jersey: Pearson Education.

Grondlund, A.E., \& Linn, R., L. (1995). Measurement and Evaluation in Teaching. New York: McMilan Publishing Company.
Hake, R.R. (1999). Analyzing Change/Gain Scores. http://www.physics.indiana.edu/sdi/Analyzin $\mathrm{g}$

Change-Gain.pdf. Matthew \& Kenneth. (2013). "The Effects of Guided Inquiry Teaching Method on Students

Achievement in Logic". Journal International Researcher. Vol.2 No. 1, pp. 135

Maya, Stefany. (2014). Pengaruh Strategi ARCS Terhadap Motivasi dan Hasil Belajar TIK Siswa Kelas VIII di SMP Negeri 4 Negara. E-Journal Program Pascasarjana Universitas Pendidikan. Ganesha Prodi Teknologi Pembelajaran. Vol.4, Halaman 1-10. Diakses pada Tanggal 26 Januari 2016.

Mulyasa, E. (2005). Menjadi guru profesional menciptakan pembelajaran kreatif dan menyenangkan. Bandung: Remaja Rosdakarya.

National Research Council (2000). Inkuiri dan StandarSatndar Pendidikan Sains Nasional. Alih Bahasa oleh: Ismunandar. Agustini, E.D. Astuti, F.R. Washington D.C: National Academy Press.

Praptiwi, L. Sarwi, dan Handayani, L. (2012). "Efektivitas model pembelajaran eksperimen inkuiri terbimbing berbantuan my own dictionary untuk meningkatkan penguasaan konsep dan unjuk kerja siswa SMP RSBI" UNNES science education journal. Vol.1 No.2, pp. 86-95.

Ratumanan, T.G. \& Laurens, T. (2006). Evaluasi Hasil Belajar yang Relevan dengan Kurikulum Berbasis Kompetensi. Surabaya: Unesa University Press.

Sanjaya, Wina. (2010). Strategi Pembelajaran Berorientasi Standar Proses Pendidikan. Jakarta: Prenada Media GrupGrup. 